\title{
Lechevalieria xinjiangensis sp. nov., a novel actinomycete isolated from radiation-polluted soil in China
}

Correspondence

Ying Huang

huangy@im.ac.cn

\author{
Wei Wang, ${ }^{1}$ Zhidong Zhang, ${ }^{1}$ Qiyong Tang, ${ }^{1}$ Jun Mao, ${ }^{1}$ Dong Wei, ${ }^{1}$ \\ Ying Huang, ${ }^{2}$ Zhiheng Liu, ${ }^{2}$ Yuhu Shi ${ }^{1}$ and Michael Goodfellow ${ }^{3}$ \\ ${ }^{1}$ Institute of Microbiology, Xinjiang Academy of Agricultural Sciences, Urumqi 830091, \\ Xinjiang Uygur Autonomous Region, People's Republic of China \\ ${ }^{2}$ State Key Laboratory of Microbial Resources, Institute of Microbiology, Chinese Academy of \\ Sciences, Beijing 100101, People's Republic of China \\ ${ }^{3}$ Division of Biology, University of Newcastle, Newcastle upon Tyne NE1 7RU, UK
}

The genus Lechevalieria Labeda et al. (2001) belongs to the family Actinosynnemataceae (Labeda \& Kroppenstedt, 2000) which also includes the genera Actinosynnema, Actinokineospora, Lentzea (Labeda et al., 2001) and Saccharothrix. The genus currently encompasses three species, Lechevalieria aerocolonigenes (Labeda et al., 2001), Lechevalieria flava (Labeda et al., 2001) and Lechevalieria fradiae (Zhang et al., 2007), which form a distinct branch in the Actinosynnemataceae phylogenetic tree based on $16 \mathrm{~S}$ rRNA gene sequences (Zhang et al., 2007); representatives of these species can be distinguished using a combination of phenotypic properties. During an investigation of microbial sources in Xinjiang, north-western China, an actinomycete, strain $\mathrm{R} 24^{\mathrm{T}}$, was isolated from a radiationcontaminated soil sample and was found to have morphological properties characteristic of the genus Lechevalieria. The aim of the present study was to determine the taxonomic status of the isolate by using a polyphasic approach. It was evident from the resultant data that the organism represents a novel species of the genus Lechevalieria.

Strain $\mathrm{R} 24^{\mathrm{T}}$ was isolated from a plate containing modified Bennett's agar (Jones, 1949) that had been inoculated with

The GenBank/EMBL/DDBJ accession number for the 16S rRNA gene sequence of strain $R 24^{\top}$ is DO898283. a soil suspension and incubated at $28{ }^{\circ} \mathrm{C}$ for 14 days. The soil sample was collected from radiation-polluted soil in the Xinjiang Uygur Autonomous Region of China. The organism was maintained on modified Sauton's agar slopes (Mordarska et al., 1972) at $4{ }^{\circ} \mathrm{C}$ and as suspensions of mycelial fragments in $20 \%(\mathrm{v} / \mathrm{v})$ glycerol at $-20{ }^{\circ} \mathrm{C}$. Biomass for the chemotaxonomic and molecular systematic analyses was prepared as described previously (Xie et al., 2002); the cells for the chemical studies were freeze-dried.

Extraction of genomic DNA, PCR-mediated amplification of the 16S rRNA and purification of the PCR product from isolate $\mathrm{R} 24^{\mathrm{T}}$ were carried out as described by Chun \& Goodfellow (1995); the PCR product was sequenced directly using a Taq DyeDeoxy Terminator cycle sequencing kit (Applied Biosystems) and an Applied Biosystems 373A DNA sequencer. The resultant 16S rRNA gene sequence was aligned manually with the corresponding sequences of representatives of genera of the family Actinosynnemataceae, as retrieved from the GenBank/ EMBL/DDBJ databases using the CLUSTAL_x 1.8 software (Thompson et al., 1997). Evolutionary distances for the neighbour-joining algorithm were calculated using the Kimura two-parameter model (Kimura, 1980). Phylogenetic trees were generated using the neighbour-joining (Saitou \& Nei, 1987) and maximum-parsimony (Fitch, 1971) algorithms from MEGA, version 3.1 (Kumar et al., 
2004), and the maximum-likelihood (Felsenstein, 1981) method from PHYLIP, version 3.5c (Felsenstein, 1993). The topologies of the resultant unrooted trees were evaluated in an analysis of the neighbour-joining dataset based on 1000 replicates. It is apparent from Fig. 1 that strain $\mathrm{R} 24^{\mathrm{T}}$ falls within the evolutionary radiation occupied by the genus Lechevalieria.

Isolate $\mathrm{R} 24^{\mathrm{T}}$ was examined for a range of diagnostic chemotaxonomic markers to determine whether or not it belongs to the genus Lechevalieria. Standard chromatographical procedures were used for the extraction and analysis of the isomers of diaminopimelic acid (Hasegawa et al., 1983; Lechevalier \& Lechevalier, 1980), the menaquinones (Collins et al., 1987), the mycolic acids (Minnikin et al., 1975), the polar lipids (Minnikin et al., 1984) and the whole-cell sugars (Hasegawa et al., 1983; Lechevalier \& Lechevalier, 1980), using appropriate controls. Fatty acids were extracted, purified, methylated and quantified by gas chromatography using the standard Microbial Identification System (MIDI; Sasser, 1990; Kämpfer \& Kroppenstedt, 1996). The G+C content of the genomic DNA of the strain was determined using the thermal denaturation method (Marmur \& Doty, 1962), with Escherichia coli K-12 as the control.

Strain $\mathrm{R} 24^{\mathrm{T}}$ contained meso-diaminopimelic acid as the wall diamino acid, galactose, mannose, rhamnose, glucose and ribose as the diagnostic whole-cell sugars (cell-wall chemotype III sensu Lechevalier \& Lechevalier, 1970), phosphatidylethanolamine and phosphatidylmethylethanolamine as major polar lipids (phospholipid type II

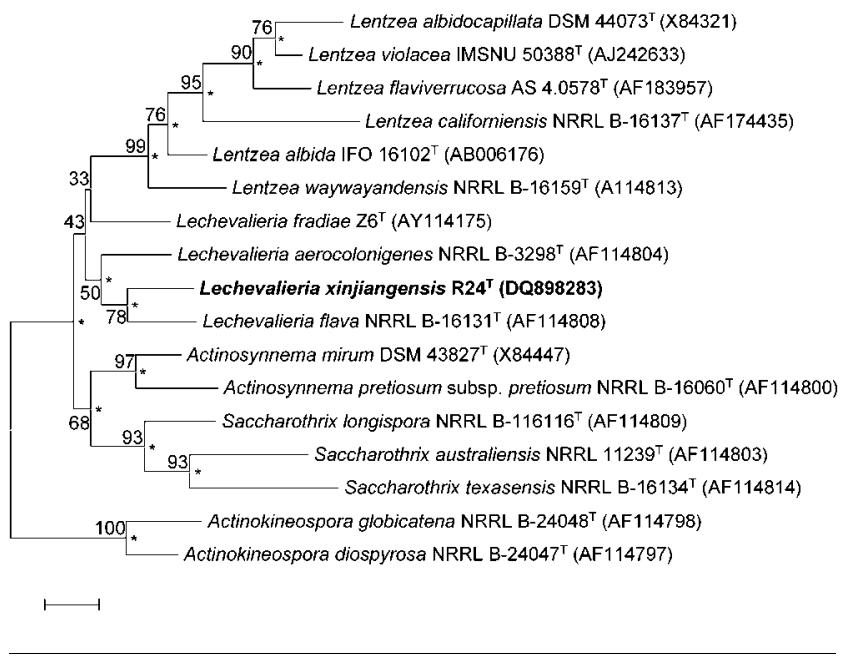

Fig. 1. Neighbour-joining phylogenetic tree, based on $16 \mathrm{~S}$ rRNA gene sequences, showing the relationships between strain R24 and representatives of the family Actinosynnemataceae. Asterisks indicate branches that were also recovered using maximumlikelihood (Felsenstein, 1981) and maximum-parsimony (Fitch, 1971) algorithms. Numbers at the nodes indicate bootstrap percentages (based on 1000 resampled datasets). Bar, 0.005 substitutions per nucleotide position. sensu Lechevalier et al., 1977), tetrahydrogenated menaquinones with nine isoprene units $\left[\mathrm{MK}-9\left(\mathrm{H}_{4}\right)\right]$ as the predominant isoprenologues, fatty acids rich in saturated iso and anteiso components and lacked mycolic acids. These properties correspond with classification of the isolate as belonging to the genus Lechevalieria (Labeda, 1986; Grund \& Kroppenstedt, 1989; Zhang et al., 2007).

It is evident from Fig. 1 that isolate $\mathrm{R} 24^{\mathrm{T}}$ is most closely related to the type strain of $L$. flava. This relationship is supported by a relatively high bootstrap percentage and by all three tree-making algorithms. The isolate shares $16 \mathrm{~S}$ rRNA gene sequence similarities with the type strains of $L$. flava, $L$. aerocolonigenes and $L$. fradiae of 98.8, 98.3 and $97.6 \%$, respectively. The $16 \mathrm{~S}$ rRNA gene sequence of the isolate contains signature nucleotides that are characteristic of members of the genus Lechevalieria (Labeda et al., 2001), the family Actinosynnemataceae (Labeda \& Kroppenstedt, 2000) and the suborder Pseudonocardineae (Stackebrandt et al., 1997).

The levels of DNA-DNA relatedness between strain R $24^{\mathrm{T}}$ and the type strains of the three Lechevalieria species were determined using the renaturation method (De Ley et al., 1970) with a Perkin Elmer Lambda 35UV/VIS spectrophotometer fitted with the Peltier temperature controller, PTP1. Genomic DNA was sheared by ultrasonication to give a mean fragment size of $300-700 \mathrm{bp}$ and the sheared preparations were adjusted to an $\mathrm{OD}_{260}$ of 2.0 in $2 \times$ SSC buffer $(1 \times$ SSC is $0.15 \mathrm{M}$ sodium chloride, $0.015 \mathrm{M}$ sodium citrate). Denaturation was achieved at $99^{\circ} \mathrm{C}$ after $10 \mathrm{~min}$; the hybridization was carried out at $82{ }^{\circ} \mathrm{C}$. The values for DNA-DNA relatedness between strain $\mathrm{R} 24^{\mathrm{T}}$ and L. aerocolonigenes NRRL B-3298 ${ }^{\mathrm{T}}$, L. flava NRRL B-16131 ${ }^{\mathrm{T}}$ and $L$. fradiae $\mathrm{ZG}^{\mathrm{T}}$ were 44,28 and $34 \%$, respectively; these values are well below the $70 \%$ cut-off point recommended for the delineation of genomic species (Wayne et al., 1987).

The morphological properties of cells of strain $\mathrm{R} 24^{\mathrm{T}}$ were examined by light microscopy (Axioskop 20; Zeiss) and scanning electron microscopy (FEI Quanta) after incubation for 14 days at $28{ }^{\circ} \mathrm{C}$. These incubation conditions were also used to determine colonial and pigmentation properties on inorganic salts-starch agar (ISP medium 4), yeast extract-malt extract agar (ISP medium 2), as described by Shirling \& Gottlieb (1966) and on modified Bennett's agar (Jones, 1949), Gauze's synthetic medium no. 1 (DSMZ medium no. 1048) and yeast-starch agar (DSMZ medium no. 1027). The production of melanin pigments was examined on peptone-yeast extract-iron agar and tyrosine agar plates (Shirling \& Gottlieb, 1966). The physiological characteristics of strain $\mathrm{R} 24^{\mathrm{T}}$ and type strains of the recognized Lechevalieria species were tested together using standard media and standard methods (Gordon et al., 1974; Yassin et al., 1995). Strain R $24^{\mathrm{T}}$ was shown to have phenotypic properties that are characteristic of the members of the genus Lechevalieria (Labeda et al., 2001; Zhang et al., 2007). The strain is an aerobic, Gram-positive, catalase-positive actinomycete that forms an extensively 
branched substrate mycelium that carries moderate amounts of aerial hyphae; the mycelium fragments into rod-like elements (Fig. 2). A range of phenotypic properties (Table 1) serve to distinguish this organism from representatives of the three Lechevalieria species with validly published names.

On the basis of the combined genotypic and phenotypic data, strain $\mathrm{R} 24^{\mathrm{T}}$ warrants classification as a novel species of the genus Lechevalieria, for which the name Lechevalieria xinjiangensis sp. nov. is proposed.

\section{Description of Lechevalieria xinjiangensis sp. nov.}

Lechevalieria xinjiangensis (xin.jiang.en'sis. N.L. fem. adj. xinjiangensis referring to Xinjiang, north-western China, the source of the isolate).

Aerobic, Gram-positive, catalase-positive, non-motile actinomycete that forms an extensively branched substrate mycelium that fragments in situ into rod-shaped elements. Moderate amounts of white to yellow aerial hyphae are formed on modified Bennett's agar, Gauze's no. 1 agar, inorganic salts-starch agar, yeast extract-malt extract agar and yeast extract-starch agar. Soluble pigments are not produced and melanin pigments are not produced on peptone-yeast extract-iron agar or tyrosine agar. Grows at temperatures between 10 and $45^{\circ} \mathrm{C}$ and at $\mathrm{pH}$ 5.0-12.0. Does not degrade elastin or Tween 80. L-Arabinose, Lcellobiose, L-fucose, myo-inositol, D-lactose, lactulose, Dmannitol, L-rhamnose and sucrose are used as sole carbon sources for energy and growth (all at 1\%,w/v). Similarly, D-alanine, L-cysteine, D-glutamic acid, hydroxy-L-proline, DL-isoleucine, L-leucinamide, L-leucine, sodium acetate, sodium propionate and sodium suberate are used as sole carbon sources at $0.1 \%(\mathrm{w} / \mathrm{v})$. L-Cysteine, L-phenylalanine

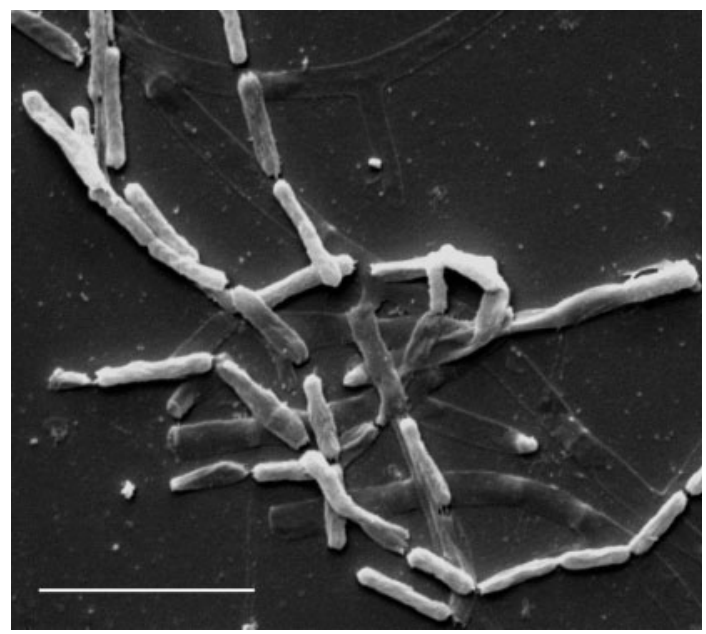

Fig. 2. Scanning electron micrograph showing rod-shaped fragments of substrate mycelium of strain $\mathrm{R} 24^{\top}$ grown on modified Bennett's agar for 14 days at $28{ }^{\circ} \mathrm{C}$. Bar, $5.0 \mu \mathrm{m}$.
Table 1. Differential phenotypic characteristics of strain R24 ${ }^{\top}$ and the type strains of Lechevalieria species

Strains: 1, R24 ${ }^{\mathrm{T}} ; 2$, L. aerocolonigenes NRRL B- $3298^{\mathrm{T}} ; 3$, L. flava NRRL $\mathrm{B}-16131^{\mathrm{T}}$; 4, L. fradiae $\mathrm{Z6}^{\mathrm{T}}$. Data were taken from this study. + , Positive; w, weakly positive; - , negative.

\begin{tabular}{|c|c|c|c|c|}
\hline Characteristic & 1 & 2 & 3 & 4 \\
\hline Nitrate reduction & + & + & - & + \\
\hline \multicolumn{5}{|l|}{ Decomposition of: } \\
\hline Casein & + & + & - & + \\
\hline Aesculin & - & + & + & - \\
\hline Hypoxanthine & - & + & + & - \\
\hline Tyrosine & - & - & - & + \\
\hline Urea & - & + & + & + \\
\hline \multicolumn{5}{|l|}{ Production of acid from: } \\
\hline Dextrin & - & - & + & + \\
\hline D-Glucose & + & + & + & - \\
\hline D-Mannose & - & + & + & - \\
\hline D-Melezitose & - & + & + & + \\
\hline L-Rhamnose & - & + & - & + \\
\hline D-Sorbitol & - & - & + & - \\
\hline Sucrose & - & - & + & + \\
\hline Trehalose & - & + & + & - \\
\hline D-Fructose & - & + & - & - \\
\hline D-Galactose & + & + & + & - \\
\hline D-Mannitol & + & + & + & - \\
\hline Inositol & + & + & + & - \\
\hline Lactose & + & + & + & - \\
\hline Salicin & - & + & - & - \\
\hline Sodium succinate & + & - & - & - \\
\hline \multicolumn{5}{|l|}{ Assimilation of: } \\
\hline Citrate & + & + & - & - \\
\hline Malonate & + & + & - & + \\
\hline Oxalate & + & + & - & - \\
\hline \multicolumn{5}{|c|}{ Growth on sole carbon sources: } \\
\hline Sorbitol & + & - & - & + \\
\hline Xylose & + & + & - & + \\
\hline \multicolumn{5}{|l|}{ Growth in the presence of: } \\
\hline $4 \% \mathrm{NaCl}$ & + & + & - & + \\
\hline $5 \% \mathrm{NaCl}$ & $\mathrm{w}$ & + & - & $\mathrm{w}$ \\
\hline $0.1 \% \mathrm{NaN}_{3}$ & - & + & + & + \\
\hline $0.1 \%$ Phenol & - & + & + & + \\
\hline $0.001 \%$ Methyl violet & + & - & + & + \\
\hline Growth at $45^{\circ} \mathrm{C}$ & + & - & + & + \\
\hline
\end{tabular}

and potassium nitrate are used as sole sources of nitrogen. Acid is produced from L-arabinose, D-cellobiose, glycerol, maltose and D-xylose, but not from D-raffinose, sodium acetate, sodium lactate, sodium malonate, sodium benzoate, sodium citrate, sodium oxalate or sodium tartrate. Additional phenotypic properties are shown in Table 1. Chemotaxonomic properties are typical of the genus Lechevalieria. The fatty acid profile is composed mainly of iso- $\mathrm{C}_{15: 0}(10.7 \%)$, anteiso- $\mathrm{C}_{15: 0}(9.8 \%)$, iso- $\mathrm{C}_{16: 0}$ $(19.9 \%)$, anteiso- $C_{17: 0}(13 \%)$, iso- $C_{17: 0}(4.0 \%), C_{16: 1}$ $(7.4 \%)$ and $\mathrm{C}_{18: 0}(4.5 \%)$. The DNA G+C content is $68.6 \mathrm{~mol} \%$. 
The type strain, $\mathrm{R} 24^{\mathrm{T}}\left(=\right.$ CGMCC $4.3525^{\mathrm{T}}=$ DSM $\left.45081^{\mathrm{T}}\right)$, was isolated from a radiation-polluted soil sample collected in the Xinjiang Uygur Autonomous Region of China. The species description is based on a single strain and hence serves as a description of the species.

\section{Acknowledgements}

The work was supported by the Hi-Tech Research and Development Program of China (grant no. 2004AA227110) and through the Royal Society-Chinese Academy of Sciences Exchange Scheme (grant no. Q814). The authors are grateful to Dr Yuhua Xin (CGMCC, China General Microbiological Culture Collection, Chinese Academy of Sciences) for providing the type strains of the Lechevalieria species.

\section{References}

Chun, J. \& Goodfellow, M. (1995). A phylogenetic analysis of the genus Nocardia with 16S rRNA gene sequences. Int J Syst Bacteriol 45, 240-245.

Collins, M. D., Howarth, O. W., Grund, E. \& Kroppenstedt, R. M. (1987). Isolation and structural determination of new members of the vitamin $\mathrm{K}_{2}$ series in Nocardia brasiliensis. FEMS Microbiol Lett 41, 35-39.

De Ley, J., Cattoir, H. \& Reynaerts, A. (1970). The quantitative measurements of DNA hybridization from renaturation rates. Eur $J$ Biochem 12, 133-142.

Felsenstein, J. (1981). Evolutionary trees from DNA sequences: a maximum likelihood approach. J Mol Evol 17, 368-376.

Felsenstein, J. (1993). PHYLIP (phylogeny inference package), version 3.5c. Distributed by the author. Department of Genome Sciences, University of Washington, Seattle, USA.

Fitch, W. M. (1971). Toward defining the course of evolution: minimum change for a specific tree topology. Syst Zool 20, 406-416.

Gordon, R. E., Barnett, D. A., Handerhan, J. E. \& Pang, C. H.-N. (1974). Nocardia coeliaca, Nocardia autotrophica, and the nocardin strain. Int J Syst Bacteriol 24, 54-63.

Grund, E. \& Kroppenstedt, R. M. (1989). Transfer of five Nocardiopsis species to the genus Saccharothrix Labeda et al. 1984. Syst Appl Microbiol 12, 267-274.

Hasegawa, T., Takizawa, M. \& Tanida, S. (1983). A rapid analysis for chemical grouping of aerobic actinomycetes. J Gen Appl Microbiol 29, 319-322.

Jones, K. L. (1949). Fresh isolates of actinomycetes in which the presence of sporogenous aerial mycelia is a fluctuating characteristic. J Bacteriol 57, 141-145.

Kämpfer, P. \& Kroppenstedt, R. M. (1996). Numerical analysis of fatty acid patterns of coryneform bacteria and related taxa. Can J Microbiol 42, 989-1005.

Kimura, M. (1980). A simple method for estimating evolutionary rates of base substitutions through comparative studies of nucleotide sequences. J Mol Evol 16, 111-120.

Kumar, S., Tamura, K. \& Nei, M. (2004). MEGA3: integrated software for molecular evolutionary genetics analysis and sequence alignment. Brief Bioinform 5, 150-163.

Labeda, D. P. (1986). Transfer of "Nocardia aerocolonigenes" (Shinobu and Kawato 1960) Pridham 1970 into the genus Saccharothrix Labeda, Testa, Lechevalier, and Lechevalier 1984 as Saccharothrix aerocolonigenes sp. nov. Int J Syst Bacteriol 36, 109-110.
Labeda, D. P. \& Kroppenstedt, R. M. (2000). Phylogenetic analysis of Sacchrothrix and related taxa: proposal for Actinosynnemataceae fam. nov. Int J Syst Evol Microbiol 50, 331-336.

Labeda, D. P., Hatano, K., Kroppenstedt, R. M. \& Tamura, T. (2001). Revival of the genus Lentzea and proposal for Lechevalieria gen. nov. Int J Syst Evol Microbiol 51, 1045-1050.

Lechevalier, H. A. \& Lechevalier, M. P. (1970). Chemical composition as a criterion in the classification of aerobic actinomycetes. Int $J$ Syst Bacteriol 20, 435-443.

Lechevalier, M. P. \& Lechevalier, H. A. (1980). The chemotaxonomy of actinomycetes. In Actinomycete Taxonomy, Special Publication 6, pp. 227-291. Arlington, VA: Society for Industrial Microbiology.

Lechevalier, M. P., De Bièvre, C. \& Lechevalier, H. A. (1977). Chemotaxonomy of aerobic actinomycetes: phospholipid composition. Biochem Syst Ecol 5, 249-260.

Marmur, J. \& Doty, P. (1962). Determination of base composition of deoxyribonucleic acid from its denaturation temperature. $J \mathrm{Mol} \mathrm{Biol}$ 5, 109-118.

Minnikin, D. E., Alshamaony, L. \& Goodfellow, M. (1975). Differentiation of Mycobacterium, Nocardia and related taxa by thin-layer chromatographic analysis of whole-organism methanolysates. J Gen Microbiol 88, 200-204.

Minnikin, D. E., O’Donnell, A. G., Goodfellow, M., Alderson, G., Athalye, M., Schaal, A. \& Parlett, J. H. (1984). An integrated procedure for the extraction of bacterial isoprenoid quinones and polar lipids. J Microbiol Methods 2, 233-241.

Mordarska, H., Mordarski, M. \& Goodfellow, M. (1972). Chemotaxonomic characters and classification of some nocardioform bacteria. J Gen Microbiol 71, 77-86.

Saitou, N. \& Nei, M. (1987). The neighbour-joining method: a new method for reconstructing phylogenetic trees. Mol Biol Evol 4, 406-425.

Sasser, M. (1990). Identification of bacteria by gas chromatography of cellular fatty acids, MIDI Technical Note 101. Newark, DE: MIDI Inc.

Shirling, E. B. \& Gottlieb, D. (1966). Methods for characterization of Streptomyces species. Int J Syst Bacteriol 16, 313-340.

Stackebrandt, E., Rainey, F. A. \& Ward-Rainey, N. L. (1997). Proposal for a new hierarchic classification system, Actinobacteria classis nov. Int J Syst Bacteriol 47, 479-491.

Thompson, J. D., Gibson, T. J., Plewniak, F., Jeanmougin, F. \& Higgins, D. G. (1997). The CLUSTAL_X windows interface: flexible strategies for multiple sequence alignment aided by quality analysis tools. Nucleic Acids Res 25, 4876-4882.

Wayne, L. G., Brenner, D. J., Colwell, R. R., Grimont, P. A. D., Kandler, O., Krichevsky, M. I., Moore, L. H., Moore, W. E. C., Murray, R. G. E. \& other authors (1987). International Committee on Systematic Bacteriology. Report of the ad hoc committee on reconciliation of approaches to bacterial systematics. Int J Syst Bacteriol 37, 463-464.

Xie, Q., Wang, Y., Huang, Y., Wu, Y., Ba, F. \& Liu, Z. (2002). Description of Lentzea flaviverrucosa sp. nov. and transfer of Saccharothrix aerocolonigenes subsp. staurosporea to Lentzea albida. Int J Syst Evol Microbiol 52, 1815-1820.

Yassin, A. F., Rainey, F. A., Brzezinka, H., Jahnke, K.-D., Weissbrodt, H., Budzikieweicz, H., Stackebrandt, E. \& Schaal, K. P. (1995). Lentzea gen. nov., a new genus of the order Actinomycetales. Int J Syst Bacteriol 45, 357-363.

Zhang, J., Xie, Q., Liu, Z. \& Goodfellow, M. (2007). Lechevalieria fradiae sp. nov., a novel actinomycete isolated from soil in China. Int $J$ Syst Evol Microbiol 57, 832-836. 